Syntax Literate: Jurnal Ilmiah Indonesia p-ISSN: 2541-0849

e-ISSN: 2548-1398

Vol. 6, No. 12, Desember 2021

\title{
HUBUNGAN POLIMORFISME GEN GAS6 (834+7G/A) DENGAN KEJADIAN PREEKLAMSIA
}

\section{Dwi Ariska, Legiran, Ferry Yusrizal}

Program Studi Ilmu Biomedik FK Universitas Sriwijaya (UNSRI), Departemen Biomedik Fakultas Kedokteran Universitas Sriwijaya (UNSRI), Bagian Obstetri dan Ginekologi RSUP Dr. Mohammad Hoesin Palembang, Indonesia

Email: ariskaaa.d@gmail.com, legiran@yahoo.com, ferry.yusrizal@gmail.com

\begin{abstract}
Abstrak
Preeklamsia (PE) adalah kelainan multisistem spesifik pada kehamilan yang ditandai oleh timbulnya hipertensi dan protein uria setelah umur kehamilan 20 minggu. Kelainan ini dianggap berat jika tekanan darah dan protein uria meningkat secara bermakna atau terdapat tanda-tanda kerusakan organ termasuk gangguan pertumbuhan janin. Faktor predisposisi dari Preeklamsia yaitu usia, paritas, status sosial ekonomi, genetik, komplikasi obtsetrik dan kondisi medis yang sudah ada sebelumnya. Tetapi mekanisme yang mendasari patogenesis PE masih belum diketahui, Sehingga disfungsi endotel vaskular, aktivasi platelet, proses inflamasi dan koagulopatik yang saling terkait dianggap bertanggung jawab atas patogenesis PE. GAS6 mengerahkan aksi biologisnya dengan mengikat ketiga reseptor tirosin kinase dari keluarga TAM (Tyro-3 / Axl / Mer). GAS6 memberikan efek antiinflamasi dalam sel endotel (Endothial cel /EC). Penelitian ini merupakan penelitian kasus kontrol (case control) yang bertujuan untuk melihat seberapa jauh pengaruh polimorfisme GAS6 $(834+7 \mathrm{G} / \mathrm{A})$ dengan kejadian preeklamsia. Sebanyak 110 subjek dilibatkan dalam penelitian ini, pengumpulan sampel dilakukan pada bulan Februari-Agustus 2020, dengan jumlah sampel masingmasing sebanyak 55 sampel kasus dan 55 sampel kontrol yang telah memenuhi kriteria inklusi. Dari hasil penelitian ini terdapat hubungan yang bermakna antara polimorfisme genotip gen GAS6 (834+7G/A) dengan kejadian preeklamsia, dengan nilai p-value 0,020, OR 2,528 dan CI 95\% lower 1,152-5,548 upper serta terdapat hubungan antara alel gen GAS6 (834+7G/A) dengan kejadian preeklamsia, dengan nilai $\rho$-value 0,011 , odd ratio (OR) 2,065 dan confidence interval (CI) $95 \%$ dengan batas bawah (lower) 1,175 dan batas atas (upper) 3,629.
\end{abstract}

Kata Kunci: polimorfisme; GAS6; preeklamsia

\section{Abstract}

Preeclampsia (PE) is a specific multisystem disorder in pregnancy characterized by the emerging of hypertension and uria protein after 20 weeks of pregnancy. This abnormality is consider as severe if blood pressure and uria protein increase significantly or there are signs of organ damage including fetal growth disorders. Predisposing factors for preeclampsia are age, parity, socioeconomic status, genetics, obstetric complications and pre-existing medical conditions. But the

$\begin{array}{ll}\text { How to cite: } & \text { Ariska. D., Legiran \& Ferry Yusrizal (2021) Hubungan Polimorfisme Gen GAS6 (834+7G/A) dengan } \\ & \text { Kejadian Preeklamsia. Syntax Literate: Jurnal Ilmiah Indonesia, 6(12). http://dx.doi.org/10.36418/Syntax- } \\ & \text { Literate.v6i12.5042 } \\ \text { E-ISSN: } & \text { 2548-1398 } \\ \text { Published by: } & \text { Ridwan Institute }\end{array}$


mechanisms which underlying the pathogenesis of PE are still unknown, so that vascular endothelial dysfunction, platelet activation, inflammatory and coagulopathic processes that are interrelated were thought to be responsible for the pathogenesis of PE. GAS6 exerts its biological action by binding to all of three tyrosine kinase receptors from the TAM family (Tyro-3 / Axl / Mer). GAS6 exerts anti-inflammatory effects in endothelial cells (Endothial cel / EC). This study is a case-control study which aims to see how far the GAS6 polymorphism $(834+7 G$ / A) affects the incidence of preeclampsia. A total of 110 subjects were involved in this study, the sample collection was carried out in February-August 2020, with a total sample of 55 case samples and 55 control samples that met the inclusion criteria. From the results of this study, there was a significant relationship between the polymorphism of the GAS6 gene $(834+7 G / A)$ and the incidence of preeclampsia, with a p-value of 0.020, OR 2.528 and $95 \%$ CI lower 1.152-5.548, and there was a relationship between the GAS6 gene allele $(834+7 G / A)$ with the incidence of preeclampsia, with a value of $\rho$-value 0.011, odds ratio (OR) 2.065 and $95 \%$ confidence interval (CI) with a l ower limit (lower) 1.175 and an upper limit (upper) 3.629.

Keywords: polymorphism; GAS6; preeclampsia

Received: 2021-11-20; Accepted: 2021-12-05; Published: 2021-12-20

\section{Pendahuluan}

Preeklamsia (PE) adalah kelainan multisistem spesifik pada kehamilan yang ditandai oleh timbulnya hipertensi dan protein uria setelah umur kehamilan 20 minggu. Kelainan ini dianggap berat jika tekanan darah dan protein uria meningkat secara bermakna atau terdapat tanda-tanda kerusakan organ termasuk gangguan pertumbuhan janin (Cunningham et al., 2010).

Berdasarkan data World Health Organization (WHO) pada tahun 2013, angka kejadian preeklamsia di seluruh dunia berkisar 0,51\%-38,4\%. Di Negara maju, angka kejadian preeklamsia berkisar 6\%-7\% (Saraswati \& Mardiana, 2016).

Berdasarkan Survei Demografi dan Kesehatan Indonesia (SDKI) tahun 2012, AKI sebesar 359 per 100.000 kelahiran hidup. Angka ini meningkat tajam dari tahun 2007 yang sudah mencapai 228. Angka kematian ibu di Indonesia jauh lebih tinggi dibandingkan negara lain di ASEAN seperti di Singapura hanya 6 per 100.000 kelahiran hidup, Brunei 33 per 100.000 kelahiran hidup, dan Filipina 112 per 100.000 kelahiran hidup, sedangkan angka kejadian di Indonesia adalah sekitar 3,8-8,5\% per 100.000 kelahiran hidup (Depkes RI, 2015). Preeklamsia termasuk penyebab kematian ibu yang tinggi sebesar 24\% (Riset Kesehatan Dasar (Riskesdas), 2013). Studi lapangan yang dilakukan di RSUP Dr. Mohammad Hoesin Palembang didapatkan 20-30 ibu hamil dengan preeklamsia perbulannya.

Faktor predisposisi dari preeklamsia yaitu usia, paritas, status sosial ekonomi, genetik, komplikasi obtsetrik dan kondisi medis yang sudah ada sebelumnya (Yogi, Hariyanto, \& Sonbay, 2014). Tetapi, mekanisme yang mendasari patogenesis PE masih belum diketahui. Disfungsi endotel vaskular, aktivasi platelet, proses inflamasi dan 
koagulopatik yang saling terkait dianggap bertanggung jawab atas patogenesis PE (Fairfield, Falank, Avery, \& Reagan, 2016). Plasentasi abnormal yang mengarah ke episode hipoksia plasenta menghasilkan pelepasan berbagai mikropartikel dari ruang intervillous ke dalam sirkulasi ibu. Mikropartikel yang bersirkulasi berpartisipasi dalam respons inflamasi maternal sistemik dengan meningkatkan interaksi antara trombosit, leukosit, dan sel endotel. Akibatnya, respon inflamasi yang berlebihan menyebabkan temuan klinis, diamati pada PE. Grow Arrest Spesific 6 (GAS6) adalah anggota dari keluarga protein yang tergantung vitamin K. GAS6 mengerahkan aksi biologisnya dengan mengikat ketiga reseptor tirosin kinase dari keluarga TAM (Tyro-3 / Axl / Mer) (Dricu et al., 2012). Telah ditunjukkan bahwa GAS6 memainkan banyak peran dalam patofisiologi gangguan autoimun, inflamasi dan metabolisme (Sainaghi \& Gibbin, 2018), dan aterosklerosis (Flynn, Pernes, Lee, Nagareddy, \& Murphy, 2019). Ada bukti bahwa GAS6 memainkan peran penting dalam pemeliharaan homeostasis vaskular dan seluler. Diduga bahwa GAS6 memberikan efek anti-inflamasi dalam sel endotel (Endothial cel /EC) dan habis ketika EC diaktifkan oleh rangsangan pro-inflamasi (Avanzi, Gallicchio, \& Saglio, 1998). Temuan ini sejalan dengan hasil yang menunjukkan bahwa GAS6 memicu aktivasi EC dalam menanggapi rangsangan inflamasi in vitro dan in vivo dengan meningkatkan interaksi antara trombosit, EC dan leukosit selama inflamasi Juga, telah dilaporkan bahwa kadar serum GAS6 berkorelasi terbalik dengan penanda inflamasi seperti tumor necrosis factor a (TNF- $\alpha$ ), interleukin 6 (IL-6) dan, penanda disfungsi EC termasuk molekul adhesi sel vaskular 1 (Vascular Cell Adhesion Molecule/VCAM-1) pada penderita diabetes (Hung, Lee, Chu, \& Shieh, 2010). Diakui bahwa pada pasien PE, peningkatan produksi sitokin dan molekul adhesi berhubungan dengan peradangan sistemik. Oleh karena itu, kami berhipotesis bahwa GAS6 dapat berkontribusi pada pengembangan PE.

Studi sebelumnya telah mengeksplorasi hubungan antara varian genetik GAS6 dan berbagai kondisi penyakit. Baru-baru ini, salah satu studi telah menunjukkan bahwa ada hubungan antara SNP 834 + 7G / A di intron 8 (rs8191974) dengan preeklamsia pada populasi Turki (82 kasus dan 68 kontrol) (Ozakpinar et al., 2016). Ini adalah satusatunya studi tentang hubungan antara polimorfisme GAS6 $834+7 \mathrm{G} / \mathrm{A}$ pada preeklamsia. Selain itu, produk gen ini berperan dalam aktivasi trombosit. Namun, fungsi tepatnya belum ditetapkan dalam PE, Seperti disebutkan sebelumnya, peradangan dan kejadian kardiovaskular termasuk disfungsi EC dan aktivasi trombosit adalah faktor risiko paling umum dalam patogenesis PE. Studi terbaru telah menunjukkan bahwa kadar GAS6 ibu berubah pada pasien dengan PE (Stephan, Kroner, \& Romer, 2019) tetapi, hasil ini masih menjadi subyek kontroversi. Sementara itu, tidak ada penelitian yang menunjukkan hubungan genetik antara GAS6 dan PE. Oleh karena itu, penelitian saat ini bertujuan untuk menganalisis Hubungan Polimorfisme GAS6 834 + 7G/A dengan Kejadian Preeklamsia. 


\section{Metode Penelitian}

Penelitian ini menggunakan desain Kasus Kontrol (Case-Control). Case Control digunakan untuk mencari hubungan seberapa jauh faktor resiko mempengaruhi terjadinya penyakit (Alamsyah, Mexitalia, Margawati, Hadisaputro, \& Setyawan, 2017). Dalam penelitian ini melihat seberapa jauh pengaruh polimorfisme GAS6 $(834+7 \mathrm{G} /$ A) dengan kejadian preeklamsia dengan perbandingan kasus dan kontrol 1:1.

Populasi pada penelitian ini adalah pasien yang datang ke poli klinik Obstetri dan Ginekologi RSUD Prabumulih Dan Puskemas Pembina Palembang, jumlah sampel pada penelitian ini adalah 54 kasus dan 54 kontrol, akan tetapi berdasarkan pertimbangan untuk antisipasi gangguan teknis sampel dan data, maka kami melakukan penambahan jumlah minimal sampel. Diputuskan jumlah masing-masing sampel tiap kelompok yaitu 55 sampel sehingga total sampel adalah 110 sampel.

\section{Hasil dan Pembahasan}

Dalam penelitian ini karakteristik subjek penelitian yang diteliti adalah usia, paritas dan riwayat hipertensi dalam keluarga.

\section{Tabel 1}

Hubungan Frekuensi Berdasarkan Usia, Paritas, Riwayat Hipertensi Dalam Keluarga

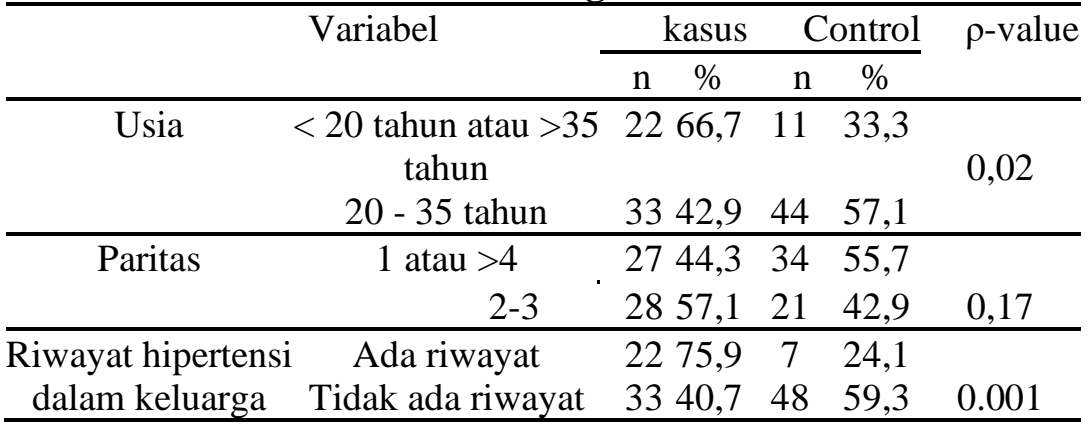

\section{A. Elektroforesis Produk PCR gen GAS6 (834+7G/A)}

Penelitian ini mengidentifikasi polimorfisme gen GAS6 $(834+7 G / A)$ pada penderita Preeklamsia dan ibu hamil normal. Gen GAS6 (834+7G/A) didapatkan melalui proses ekstraksi DNA dan analisis genotip dengan metode PCR- RFLP dari sampel darah.

Ekstraksi/isolasi DNA sampel darah dilakukan dengan pemeriksaan polimerase chain reaction (PCR) gen GAS6 (834+7G/A) menggunakan primer:

1. Forward primer 5',TTC CCT CAA GAA AGA GCC CG-3' Gas6 E8-F

2. Reverse primer 5'-TCT CAT CCC AAA CCT CCA CA-3' Gas6 E8-R (Ozakpinzr, dkk.2015)

Produk hasil PCR berupa amplikon dievaluasi untuk membuktikan keberhasilan ekstraksi DNA yang telah dilakukan dengan cara elektroforesis melalui media gel agarose konsentrasi $2 \%$ yang mengandung ethidium bromide selama 50 menit dengan kekuatan 100 volt dan kecepatan $400 \mathrm{~mA}$, hasil electroforesis 
kemudian divisualisasi dengan menggunakan sinar Ultra Violet (UV) dan dibaca pada monitor komputer (Ozakpinar et al., 2016).

\section{B. RFLP Menggunakan Enzim HhaI pada Gen GAS6}

Setelah tahap PCR dilanjutkan dengan Restriction Fragmen Length Polymorpishm (RFLP) yaitu tahapan restriksi menggunakan enzim HhaI, dengan cara mencampur produk hasil PCR (amplikon) dengan enzim retriksi HhaI pada suhu $37^{\circ} \mathrm{C}$ selama 2 jam. Setelah proses RFLP selesai dilanjutkan dengan tahap eletroforesis kembali menggunakan gel agarose $4 \%$ yang mengandung ethidium bromide selama 60 menit dengan kekuatan 80 volt dan 400 mA (Ozakpinar et al., 2016). Adanya polimorfisme gen GAS6 (834+7G/A) akan menyebabkan terbentuknya situs retriksi baru yang dikenali oleh enzim HhaI. Situs pengenalan enzim HhaI:

$$
\begin{aligned}
& 5, \ldots \text { GAA } \ldots .3 \\
& 3^{\prime}, \ldots \text { AAA } \ldots .5
\end{aligned}
$$

Polimorfisme gen GAS6 (834+7G/A) akan tervisualisasi dengan menggunakan sinar ultraviolet, terlihat 3 variasi genotip hasil pemotongan enzim retriski HhaI terhadap produk ekstraksi/isolasi DNA, yaitu:

1. Genotip GG (Wild Type) menunjukkan gambaran 1 pita yaitu 481-bp bands yang berarti tidak terjadi pemotongan pada kedua alel

2. Genotip AG (mutant heterozygote) menunjukkan gambaran 3 pita yaitu 481-bp bands, 345-bp bands, dan 136-bp bands yang berarti terjadi pemotongan pada satu alel dan tidak terjadi pemotongan pada alel pasangannya

3. Genotip AA (mutant homozygote) menunjukkan gambaran 2 pita yaitu 345-bp bands dan 136-bp bands yang berarti tidak terjadi pemotongan pada satu alel (Ozakpinzr,dkk.2015)

C. Analisis Hubungan Polimorfisme Genotip Gen GAS6 (834+7G/A) dengan Kejadian Preeklamsia

Setelah semua subjek penelitian menjalani proses isolasi DNA, PCR dan RFLP, maka didapatkan analisis hubungan polimorfisme genotip gen GAS6 (834+7G/A) dengan kejadian preeklamsia dapat dilihat pada tabel 2 dibawah ini:

Tabel 2

Hubungan Frekuensi Genotip pada Polimorfisme Gen GAS6 (834+7G/A)

\begin{tabular}{|c|c|c|c|c|}
\hline \multicolumn{4}{|c|}{ Variabel GenotipKelompok Subjek penelitian $\rho$-value } & \multirow{2}{*}{$\frac{\text { OR }}{\text { CI 95\% (min-max) }}$} \\
\hline & Kasus & Kontrol & & \\
\hline GG & $27(49,9 \%)$ & $39(59,1)$ & & \\
\hline AA & $20(58,8 \%)$ & $14(41,2 \%)$ & 0,03 & - \\
\hline $\mathrm{AG}$ & $8(80,0 \%)$ & $2(20,0 \%)$ & & \\
\hline $\mathrm{AG}+\mathrm{AA}$ & $28(63,6)$ & $16(36,4 \%)$ & 0,02 & 2,528 \\
\hline GG & $27(40,9 \%)$ & $39(59,1)$ & & $1,152-5,548$ \\
\hline
\end{tabular}
dengan Kejadian Preeklamsia 
Tabel 2 menerangkan bahwa distribusi frekuensi genotip polimorfisme gen GAS6 (834+7G/A) dengan kejadian preeklamsia bahwa pada kelompok kasus dengan diperoleh hasil AG dan AA sebanyak 28 responden $(63,6 \%)$ dan genotip wild type (GG) sebanyak 27 responden $(40,9 \%)$ sedangkan pada kelompok kontrol diperoleh hasil genotip mutant (AG dan AA) sebanyak 16 responden $(36,4 \%$ ) dan genotip GG 39 responden $(59,1 \%)$.

Dari hasil analisis uji chi-square didapatkan nilai p-value 0,020 dan OR 2,528, dengan lower 1,152-5,548 upper yang artinya terdapat hubungan yang bermakna antara polimorfisme gen GAS6 (844+7G/A) dengan kejadian preeklamsia.

D. Analisis Hubungan Frekuensi Alel pada Polimorfisme Gen GAS6 (834+7G/A) dengan Kejadian Preeklamsia

Untuk mengetahui hubungan antara Polimorfisme Alel Gen GAS6 (834+7G/A) dengan Kejadian Preeklamsia dilakukan dengan uji Chi-Square. Analisis hubungan antara Polimorfisme Alel Gen GAS6 $(834+7 G / A)$ dengan Kejadian Preeklamsia dapat dilihat pada tabel 3 dibawah ini:

Tabel 3

Hubungan Frekuensi Alel pada Polimorfisme Gen GAS6 (834+7G/A) dengan Kejadian Preeklamsia

\begin{tabular}{ccccc}
\hline Alel & Kasus & Kontrol & $\rho$-value & OR \\
\hline & $\mathrm{n}=\%$ & $\mathrm{n}=\%$ & $\mathrm{CI} 95 \%$ (min-max) \\
\hline $\mathrm{A}$ & $48(61,5)$ & $30(38,5)$ & 0.01 & 2,065 \\
\hline $\mathrm{G}$ & $62(43,7)$ & $80(56,3)$ & $1,175-3,629$ \\
\hline Total & $110(100)$ & $110(100)$ & \\
\hline
\end{tabular}

Dari hasil tabel 3 didapatkan Alel $\mathrm{G}$ banyak terdapat pada kelompok kontrol yaitu 80 Alel (56,3\%) dan pada kelompok kasus Alel G terdapat 62 alel (43,7\%), Sedangkan Alel A banyak terdapat pada kelompok kasus yaitu 48 Alel $(61,5 \%)$ dan pada kelompok kontrol 30 Alel $(38,5 \%)$.

Berdasarkan hasil uji Chi-square diperoleh nilai $\rho$-value 0,011 dengan odd ratio (OR) 2,065 dan confidence interval (CI) 95\% dengan batas bawah (lower) 1,175 dan batas atas (upper) 3,629 yang artinya terdapat hubungan yang bermakna antara polimorfisme gen GAS6 (834+7G/A) dengan kejadian preeklamsia.

\section{Tabel 4}

Analisis hubungan faktor-faktor risiko dengan kejadian preeklamsia

\begin{tabular}{|c|c|c|c|c|c|c|}
\hline Variabel & & & $\mathbf{N}$ & p-value & $\operatorname{Exp}(\beta)$ & R-Square \\
\hline Polimorfise & Gen & GAS6 & & 0,007 & 0,300 & \\
\hline$(834+7 \mathrm{G} / \mathrm{A})$ & & & 110 & & & 0,258 \\
\hline Usia & & & & 0,016 & 0,316 & \\
\hline Riwayat Keluarga & Hipertensi & Dalam & & 0.002 & 0,194 & \\
\hline
\end{tabular}

Berdasarkan tabel 4 diketahui bahwa ada 3 faktor yang mempengarhi kejadian preeklamsia dengan kekuatan pengaruh secara keseluruhan sebesar 0,258 artinya 
kekuatan secara keseluruhan maseh lemah dengan p- value polimorfisme gen GAS6 (834+7G/A) 0,007, usia 0,016 dan riwayat hipertensi dalam keluarga 0,002, dari 3 faktor yang mempenngaruhi didapatkan variabel riwayat hipertensi dalam keluarga yang paling berpengaruh terhadap kejadian preeklamsia.

\section{Kesimpulan}

Distribusi frekuensi karekteristik pada kasus preeklamsia lebih banyak terjadi pada umur 20-35 tahun sebesar 33 responden $(57,1 \%)$ dengan kelompok paritas yang berisiko 1 atau $>4$ anak yaitu 27 responden $(44,3 \%)$ dan yang ada riwayat hipertensi dalam keluarga sebesar 22 responden $(75,9 \%)$.

Terdapat hubungan yang bermakna antara polimorfisme genotip gen GAS6 (834+7G/A) dengan kejadian Preeklamsia, dengan nilai p-value 0,020, OR 2,528 dan CI 95\% lower 1,152-5,548 upper. Terdapat hubungan yang bermakna antara polimorfisme alel gen GAS6 (834+7G/A) dengan kejadian preeklamsia, dengan nilai $\rho$-value 0,011 , odd ratio (OR) 2,065 dan Confidence Interval (CI) 95\% dengan batas bawah (Lower) 1,175 dan batas atas (upper) 3,629. 


\section{BIBLIOGRAFI}

Alamsyah, Dedi, Mexitalia, Maria, Margawati, Ani, Hadisaputro, Suharyo, \& Setyawan, Henry. (2017). Beberapa faktor risiko gizi kurang dan gizi buruk pada balita 12-59 bulan (studi kasus di kota Pontianak). Jurnal Epidemiologi Kesehatan Komunitas, 2(1), 46-53. Google Scholar

Avanzi, Gian Carlo, Gallicchio, Margherita, \& Saglio, Giuseppe. (1998). Hematopoietic growth factors in autologous transplantation. Biotherapy, 10(4), 299-308. Google Scholar

Cunningham, F. Gary, Leveno, K. J., Bloom, S. L., Hauth, J. C., Rouse, D. J., \& Spong, C. Y. (2010). Williams Obstetric 23rd Edition. United States: The McGraw-Hill Companies Inc. Google Scholar

Depkes RI. (2015). Keputusan Menteri Kesehatan nomor 52 tahun 2015. jakarta. Google Scholar

Dricu, Anica, Purcaru, Stefana Oana, Budiu, Raluca, Ola, Roxana, Tache, Daniela Elise, \& Vlad, Anda. (2012). Epigenetic Alteration of Receptor Tyrosine Kinases in Cancer. DNA Methylation-From Genomics To Technology, 303. Google Scholar

Fairfield, Heather, Falank, Carolyne, Avery, Lindsey, \& Reagan, Michaela R. (2016). Multiple myeloma in the marrow: pathogenesis and treatments. Annals of the New York Academy of Sciences, 1364(1), 32. Google Scholar

Flynn, Michelle C., Pernes, Gerard, Lee, Man Kit Sam, Nagareddy, Prabhakara R., \& Murphy, Andrew J. (2019). Monocytes, macrophages, and metabolic disease in atherosclerosis. Frontiers in Pharmacology, 10, 666. Google Scholar

Hung, Yi Jen, Lee, Chien Hsing, Chu, Nain Feng, \& Shieh, Yi Shing. (2010). Plasma protein growth arrest-specific 6 levels are associated with altered glucose tolerance, inflammation, and endothelial dysfunction. Diabetes Care, 33(8), 18401844. Google Scholar

Ozakpinar, Ozlem Bingol, Sahin, Sadık, Verimli, Nihan, Simsek, Gulhayat Golbasi, Maurer, Anne Marie, Eroglu, Mustafa, Tetik, Sermin, \& Uras, Fikriye. (2016). Association between the growth arrest-specific 6 (Gas6) gene polymorphism c. 834+ 7G> A and preeclampsia. The Journal of Maternal-Fetal \& Neonatal Medicine, 29(7), 1149-1153. Google Scholar

Riset Kesehatan Dasar (Riskesdas). (2013). Riset Kesehatan Dasar (Riskesdas). Jakarta: Badan Litbangkes, Depkes RI. Google Scholar

Sainaghi, Pier Paolo, \& Gibbin, Antonello. (2018). Vitamin D, inflammation and osteoporosis in rheumatoid arthritis. The Open Rheumatology Journal, 12(1). Google Scholar 
Dwi Ariska, Legiran, Ferry Yusrizal

Saraswati, Nuning, \& Mardiana, Mardiana. (2016). Faktor Risiko Yang Berhubungan Dengan Kejadian Preeklampsia Pada Ibu Hamil (Studi Kasus Di Rsud Kabupaten Brebes Tahun 2014). Unnes Journal of Public Health, 5(2), 90-99. Google Scholar

Stephan, Tobias, Kroner, U. W. E., \& Romer, Rolf L. (2019). The pre-orogenic detrital zircon record of the Peri-Gondwanan crust. Geological Magazine, 156(2), 281307. Google Scholar

Yogi, Etika Desi, Hariyanto, Hariyanto, \& Sonbay, Elfrida. (2014). Hubungan Antara Usia Dengan Preeklampsia Pada Ibu Hamil Di POLI KIA RSUD Kefamenanukabupaten Timor Tengah Utara. Jurnal Delima Harapan, 1(1), 10-19. Google Scholar

\section{Copyright holder:}

Dwi Ariska, Legiran, Ferry Yusrizal (2021)

\section{First publication right:}

Syntax Literate: Jurnal Ilmiah Indonesia

This article is licensed under:

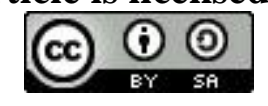

